\title{
Isolation, Expansion, Differentiation and Growth Kinetics Essay in Mesenchymal Stem Cells Culture from the Bone Marrow of Collared Peccaries (Tayassu tajacu)
}

\author{
Napoleão Martins Argôlo Neto, Matheus Levi Tajra Feitosa, Simony Silva Sousa, \\ Pablo Brandão Fernandes, Gérson Tavares Pessoa, Dayseanny de Oliveira Bezerra, \\ Hatawa Melo de Almeida, Yulla Klinger Pereira de Carvalho, Andressa Rego da Rocha, \\ Laís Meireles Costa Silva \& Maria Acelina Martins de Carvalho
}

\begin{abstract}
Background: There are few studies on stem cell isolation in wild animals that provide isolation and culture protocols of these cells in vitro. Among the wild species studied, we present the collared peccary (Tayassu tajacu) as a model with potential to obtain and use MSC in preclinical studies. These animals are phylogenetically close to the domestic pig, popularly known as peccaries and found naturally in South America, Central America and the South of the United States. The aim of the present study was to establish a protocol for the isolation, in vitro cell expansion, differentiation and assessment of the stromal MSC growth curve before and after thawing.

Materials, Methods \& Results: Mesenchymal stem cells (MSC) from collared peccary bone marrow (Tayassu tajacu) were isolated and expanded by centrifuge in Ficoll ${ }^{\circledast}$ solution and cultured in DMEM ${ }^{\circledast}$ High Glucose medium. The culture was assessed by assays of colony forming units CFU-F and growth curve by saturation (GCS). Cultures in the third passage, with $70 \%$ confluence, were replicated at $10^{5}$ cells $/ \mathrm{mL}$ concentration in the culture media to induce osteogenic cell differentiation and adipogenic cell differentiation, respectively. The MSC were frozen in nitrogen for 40 days, thawed and re-assessed for cell viability and GCS.

Discussion: The bone marrow collected presented high mononuclear cellularity, with a mean variability of $94.5 \%$ and $60.83 \pm 4.27$ UFC were identified in the samples and cells with fibroblast-like-cell morphology were observed. When they were expanded, the mean cell viability was $95 \%$, the mean cell concentration obtained was $233.31 \pm 20.04$ cells per $25 \mathrm{~cm}^{2}$ bottle and the culture reached the growth plateau in GCS between the 13th and 16th day. The osteoblastic cell differentiation assay showed after 18 days, morphology similar to osteoblasts, with irregular cytoplasm limits, cell prolongation formation and flattened appearance. After staining with Alizarin Red, the nucleus presented a wine red coloring and the cytoplasm, more basophilic and well-defined, with calcium deposits inside the cells. The cultures submitted to adipogenic differentiation were large, hexagonal, irregular and presented birrefringent cytoplasm granules after the third week of culture. When stained with Oil Red it was observed that the cytoplasm granules were scattered small fat vacuoles and stained maroon. The viability after thawing was $78 \%$ and the mean cell concentration obtained in GCS was $199.71 \pm 14.72$ cells per $25 \mathrm{~cm}^{2}$ bottle. The curves reached the saturation plateau early, on the eighth day of observation. From then onwards the cultures entered became exhausted and the cell concentration of the samples decreased progressively until minimum values. These results showed the presence of a well-defined MSC population in the collared peccary bone marrow with a high rate of replication in vitro and potential for differentiation confirmed by the adipogenic and osteogenic lines. The cryopreservation technique adopted presented satisfactory results, but indicated a significant cell stress after thawing that justifies investigation of the apoptosis rates induced post thawing in the species. Furthermore, the bone marrow collection did not harm the animals and the facility of stromal MSC isolation and culture qualifies the collared peccary as a viable alternative model to obtain MSC and for studies in the area of cell therapy.
\end{abstract}

Keywords: mesenchymal stem cells, Tayassu tajacu, bone marrow. 


\section{INTRODUCTION}

Mesenchymal stem cells (MSC) are multipotent adult stem cells that can be isolated from a diverse number of organs and have high capacity to differentiate giving rise to mesodermal and non-mesodermal tissues [1,2]. Research with this type of cell has become well known in recent decades due to the discovery of their great plasticity [3-5] and the positive results in the experimental treatment of various diseases in animal and man [6,7].

The animal models used in stem cell research include that of the pig (Artiodactyla: suidae) because of its biological, anatomic, physiological and nutritional similarities with humans [8-10]. However, interest has also grown in the use of wild animals as alternative models to those currently used because Brazilian public policies need to be established for rational use of these animals in research and production, thus contributing to their preservation [11]. It is believed that the study the wild animals MSC performance and plasticity in vitro constitutes an important alternative for the formation and preservation of genomic cell banks.

Among the wild species studied, we present the collared peccary (Tayassu tajacu) as a model with potential to obtain and use MSC in preclinical studies. These animals are phylogenetically close to the domestic pig [12] and belong to the Artiodactila order, Tayassuidae family, popularly known as peccaries and found naturally in South America, Central America and the South of the United States [13].

The aim of the present study was to establish a protocol for the isolation, in vitro cell expansion, differentiation and assessment of the stromal MSC growth curve before and after thawing.

\section{MATERIALS AND METHODS}

\section{Animals}

Four healthy male collared peccaries (Tayassu tajacu), $3 \pm 1.5$ years old (mean $+\mathrm{SD}$ ), were used as bone marrow donors, kept in individual (4.2 x 3.6m) stalls cleaned daily and fed commercial pig diet (minimum crude protein - $18 \%$, ether extract $-1.5 \%$, fibrous material $12 \%$, Calcium - $1.3 \%$ and phosphorus $-0.4 \%$ ), with corn, fruit, tubers, regional vegetables and water ad libitum.

The sample was calculated a $99 \%$ with confidence interval for sample calculation for finite populations [14].
Tissue culture media

The base culture media Dulbecco's Modified Eagle's (DMEM) pH 7.4 was used, high glucose, sodium pyruvate, phenol red $\left(\text { SIGMA }^{\circledR}\right)^{1}$, supplemented with $15 \%$ fetal bovine serum $\left(\mathrm{GIBCO}^{\circledR}\right)^{2}, 1 \%$ penicillin $(100 \mathrm{UI} / \mathrm{mL})$ and streptomycin $(100 \mu \mathrm{g} /$ $\mathrm{mL})\left[\mathrm{SIGMA}^{\circledR}\right]^{1}, 1 \%$ L-glutamine $(2 \mu \mathrm{M})\left[\mathrm{GIBCO}^{\circledR}\right]^{2}$, $1 \%$ non-essential amino acids $\left(\mathrm{GIBCO}^{\circledR}\right)^{2}, 0.001 \%$ $\beta$-mercaptoethanol $(55 \mathrm{mM})$ [SIGMA $\left.^{\circledR}\right]^{1}$ and $5.96 \mathrm{~g}$ HEPES buffer solution (4-(2-hydroxyethyl)-1-piperazineethanesulfonic acid) $\left[\mathrm{SIGMA}^{\otimes}\right]^{1}$, heated to $37^{\circ} \mathrm{C}$.

To freeze the cells, the culture media was used supplemented with $40 \%$ fetal bovine serum, HEPES buffer solution and $10 \%$ dymethyl sulfoxide (SIG$\left.\mathrm{MA}^{\circledR}\right)^{1}$ chilled to $4^{\circ} \mathrm{C}$ and handled in a dark chamber.

\section{Bone marrow collection}

The collared peccary were pre-anethetized with ketamine chloridrate $(5 \mathrm{mg} / \mathrm{Kg})$ [Agribands $\left.{ }^{\circledR}\right]^{3}$ associated to intramuscular midazolan $(0.5 \mathrm{mg} / \mathrm{Kg})$ $\left[\text { Cristália }{ }^{\circledR}\right]^{4}$, induced with intravenous propofol ( $5 \mathrm{mg} /$ $\mathrm{Kg})\left[\text { Cristália }{ }^{\circledR}\right]^{4}$, intubated with an orotracheal tube with cuff and maintained with Isofluorane $\left(\text { Cristália }^{\circledR}\right)^{4}$ in a half-closed anesthetic circuit. The animals were monitored by a heart monitor and oximetry.

Trichotmony was carried out and antisepsis with $10 \%$ povidone-iodine $10 \%\left(\text { Lapon }^{\circledR}\right)^{5}$ of the right ileac crest region of the animals and a $11 \mathrm{Gx} 4$ " bone marrow biopsy needle (Cardinal Health $\left.{ }^{\circledR}\right)^{6}$ was inserted in the ileac crest in the cranium-caudal direction with a dorsal inclination of approximately $35^{\circ}$, attached to a heparinized 5000UI/5mL Luer lock syringe (Bergamo $\left.^{\circledR}\right)^{7}$. Eight $\mathrm{mL}$ bone marrow blood were aspirated and the animals were medicated with amoxicillin trihydrate $(20 \mathrm{mg} / \mathrm{kg})\left[\mathrm{Virbac}^{\circledR}\right]^{8}$ and sodium dipyrone $(25 \mathrm{mg} / \mathrm{kg})$ [Ourofino $\left.{ }^{\circledR}\right]^{9}$, added to water, once a day for five post-operative days.

\section{Primary MSC culture}

The bone marrow aspirate was filtered in a square mesh sieve $(0.15 \mathrm{~mm})$ to remove debris, such as fat and bone fragments and diluted in sterile salinephosphate buffer solution (PBS) [Cultilab $\left.{ }^{\circledR}\right]^{10}$ at $1: 1$. The solution was carefully placed in a cone-bottomed tube containing the same proportion of Ficoll Hystopaque solution $\left(\mathrm{SIGMA}^{\circledR}\right)^{1}$ and centrifuged at $300 \mathrm{~g}$ for $25 \mathrm{~min}$ at $20^{\circ} \mathrm{C}$. The mononuclear cell fraction was aspirated, diluted in sterile PBS with $1 \%$ antibiotic and again centrifuged at $300 \mathrm{~g}$ for $10 \mathrm{~min}$ at $4^{\circ} \mathrm{C}$. 
The supernatant was discarded and the pellet was re-suspended in supplemented base growth medium. One aliquot of the sample was diluted in Tripan Blue $0.2 \%\left(\mathrm{GIBCO}^{\circledR}\right)^{2}$ at $1: 1$, from which the cell concentration and viability were determined in a Neubauer chamber.

The cells were replicated in cell culture plate wells (TPP®) 11 , at the density of $10^{6}$ cells/well, in supplemented base culture media and incubated at $37^{\circ} \mathrm{C}, 5 \%$ carbon dioxide and $95 \%$ moisture.

The culture media was changed twice a week until a single homogeneous cell layer was formed with $80 \%$ confluence. The culture was then washed with PBS solution with $1 \%$ antibiotic, treated with trypsinEDTA solution $\left(\mathrm{SIGMA}^{\circledR}\right)^{1}$, and incubated at $37^{\circ}$ for $10 \mathrm{~min}$. The trypsin was inactivated adding base culture media and separated from the cell fraction by centrifuge. The supernatant was discarded and the pellet resuspended in supplemented base media and new cell count was made. The cells in suspension, from the four bone marrow samples collected, were used to assess the colony forming units (CFU-F) and cell expansion. For each sample, the cultures were trypsinized and the cells plated in duplicate in $25 \mathrm{~cm} 2$ bottles $\left(\mathrm{TPP}^{\circledR}\right)^{11}$ at a concentration between $1 \times 105$ and $2.2 \times 10^{5}$ cells $/ \mathrm{mL}$ for each one of these purposes, respectively.

Cfu - fassay

The cells obtained were re-suspended in the culture media to a concentration of $2.2 \times 10^{5}$ viable cells $/ \mathrm{mL}$ and $2 \mathrm{~mL}$ of these cells suspension were placed in each well of a six-well plate $\left(4.9 \times 10^{4}\right.$ cells/ $\mathrm{cm}^{2}$ ). The culture media was changed on days 3 and 8 of culture. On the 20th day, some cultures were fixed and stained with Giemsa. The CFU-F that displayed five or more cells was scored under an inverted microscope. Colonies with 4 cells were counted when one of them presented two nuclei. Colonies whose morphology clearly differed from the MSC morphology (fibroblastoid or fusiform) were excluded from the results. Photographs were taken by a digital camera coupled to an optical microscope12, using a x 10 lens, 1.5 zoom and $37.5 \%$ magnification.

\section{MSC subculture}

After obtaining homogeneous cultures of adherent cells and fibroblast-like-cell morphology, the cells were kept incubated at $37^{\circ} \mathrm{C}$, with $5 \%$ carbon dioxide and $95 \%$ moisture. The culture media was replaced weekly until it reached $90 \%$ confluence. The culture was assessed for maintenance of the initial morphology by a phase contrast inverted microscope $\left(\text { Zeiss }^{\circledR}\right)^{12}$ and photographed with a digital camera $\left(\text { Sony }{ }^{\circledR}\right)^{13}$ coupled to the microscope, using an image capture software version 3.5.9 (Spot Basic $\left.^{\circledR}\right)^{14}$.

The cultures were washed, trypzinized, assessed for cell morphology, concentration and viability and replicated with twice the original area (1:2) until the seventh passage, after which a replication rate was adopted of 1:4 until the 15th passage. These measures were adopted empirically to maintain constant growth rate and allow handling of the cultures only twice a week. Cell samples in the fourth passage were washed, trypsinized, transferred to cryopreservation tubes at $1 \mathrm{x}$ $10^{5}$ cells $/ \mathrm{mL}$ concentration in freezing medium at $4^{\circ} \mathrm{C}$ and kept at $-80^{\circ} \mathrm{C}$ for $6 \mathrm{~h}$. The culture was then frozen in liquid nitrogen at $-196^{\circ} \mathrm{C}$ and stored.

\section{Differentiation assay}

Cultures in the third passage, with $70 \%$ confluence, were replicated at 105 cells $/ \mathrm{mL}$ concentration in the culture media to induce osteogenic cell differentiation $\left(\mathrm{GIBCO}^{\circledR} \text { - StemPro }{ }^{\circledR}\right)^{2}$ and adipogenic cell differentiation $\left(\mathrm{GIBCO}^{\circledR} \text { - StemPro }{ }^{\circledR}\right)^{2}$, respectively.

The culture media remained incubated and the cell differentiation medium were replaced every $72 \mathrm{~h}$. After 21 days the differentiation media were discarded and the cultures fixed in paraformaldehyde at $4 \%$. The cultures submitted to osteogenic differentiation were stained with Alizarin Red $\left(\text { SIGMA }^{\circledR}\right)^{1}$ to identify intracellular calcium deposits and the cultures submitted to adipogenic differentiation were stained with Oil Red $\left(\mathrm{SIGMA}^{\circledR}\right)^{1}$, to identify fat vacuoles dispersed in the cell cytoplasm.

Pre-freezing growth kinetics assays

Cultures in the fourth passage were plated at 1 $\mathrm{x} 105$ cells/mL concentration in $25 \mathrm{~cm}^{2}$ bottles in a total of 20 bottles. The culture media was replaced every $72 \mathrm{~h}$ and one bottle was trypsinized daily, and the cell concentration and viability were calculated over 20 days. The values obtained were tabled and organized in a linear regression graph to characterize the in vitro cell kinetics under saturation.

Post-freezing growth kinetics assays

After 40 days, 20 cell samples were thawed at $37^{\circ} \mathrm{C}$ in a water bath and transferred, along with the freezing medium ( $1 \mathrm{~mL}$ ), to $25 \mathrm{~cm}^{2}$ culture bottles, in 
a total of 20 bottles, containing triple the volume of supplemented base medium $(3 \mathrm{~mL})$. The cells were kept incubated for $24 \mathrm{~h}$ and only after this period were washed with PBS solution and the culture media was replaced again.

The culture media was replaced every 72 $\mathrm{h}$ and one bottle was trypsinized daily, and the cell concentration and viability were calculated over 20 days. The values obtained were organized in linear regression graph.

\section{Statistical analysis}

The statistical analysis was carried out using the electronic data spreadsheet $\left(\text { Excel }^{\circledR}\right)^{15}$ and the statistical analysis program version $8.0\left(\mathrm{SAS}^{\circledR}\right)^{16}$.

The means and standard deviations of the percentage of viability and cell kinetics of the cultures were assessed.

The level of rejection of the null hypothesis was $1 \%(P \leq 0.01)$ for both analyses.

\section{RESULTS}

All the bone marrow samples collected, separated by density gradient, presented a discreet whitish halo with a misty aspect at the Ficoll solution and blood plasma interface (Figure 1A). The mononuclear fraction obtained from this halo had a mean cell concentration of $5.86 \pm 0.5 \times 106$ cells per mL (Table 1 ).

After $48 \mathrm{~h}$ culture, the cells collected were sparsely deposited in cell clusters, with cell overlay and poorly defined cytoplasmic limits. After $96 \mathrm{~h}$ culture, a large percentage of mononuclear cells remained in suspension until the first washing with PBS. There was significant reduction in the cells in suspension after this wash, a time when the first clusters were observed of adherent cells and fibroblast-like-cell morphology (Figure 1B).

During the CFU-F assay, an average of $60.83 \pm$ 4.27 parent mesenchymal cell colonies were identified (equivalent to $2.8 \times 10^{4}$ cells) in the samples studied (Table 1). The cells maintained their fibroblast-like-cell characteristic and showed radial growth, and tended to coalesce between the colonies and single cell layer formation.

Progressive reduction was observed in the percentage of mononuclear cells in suspension after each wash and after 20 days culture, there were only mesenchymal cell clusters (Figure 1C). These cells coalesced and formed a single cell layer with $80 \%$ con- fluence after 25 days culture. The cells were large and flattened, with fibroblast morphology, placed sideways one to another, emitting cytoplasm attic prolongations as far as the more distant cells (Figure 1D).

During the cell differentiation assay, in the cultures submitted to osteogenic differentiation, progressive morphological alterations were observed starting on the 11th day in culture, with an increase in the nucleus: cytoplasm ratio, cuboid shaped cells with a spherical central nucleus. After 18 days, the cells acquired morphology similar to osteoblasts, with irregular cytoplasm limits, cell prolongation formation and flattened appearance (Figure 2A and B). After staining with Alizarin Red, the nucleus presented a wine red coloring and the cytoplasm, more basophilic and well-defined, with calcium deposits inside the cells (Figure 2C and D). The cultures submitted to adipogenic differentiation were large, hexagonal, irregular and presented birrefringent cytoplasm granules after the third week of culture. When stained with Oil Red it was observed that the cytoplasm granules were scattered small fat vacuoles and stained maroon (Figure $2 \mathrm{E}$ and $\mathrm{F})$.

The pre-freezing growth curves presented on average $233.31 \pm 20.04$ cells per $25 \mathrm{~cm}^{2}$ a bottle. The curves ascended evenly until the ninth day of observation, when the cell concentration of the samples increased progressively until it reached the curve saturation plateau between the 13th and 16th day. After the interval, the culture became exhausted and the cell concentration declined progressively (Graph 1).

The mean cell viability during the realization of this growth curve was $91.25 \%$, but viability declined after the 14th day of observation.

During the expansion of the culture through 15 passages, it was observed that the MSC preserve the fibroblast-like-cell morphology observed in the isolation of the culture. A $95 \%$ mean viability was measured during the cell expansion, that remained constant throughout the experiment. After thawing the culture, the cell viability fell to $78 \%$. The growth curve cell kinetics assay presented, on average, $199.71 \pm 14.72$ cells per $25 \mathrm{~cm}^{2}$ bottle. The curves reached the saturation plateau early, on the eighth day of observation. From then onwards the cultures entered became exhausted and the cell concentration of the samples decreased progressively until minimum values (Graph 2). 


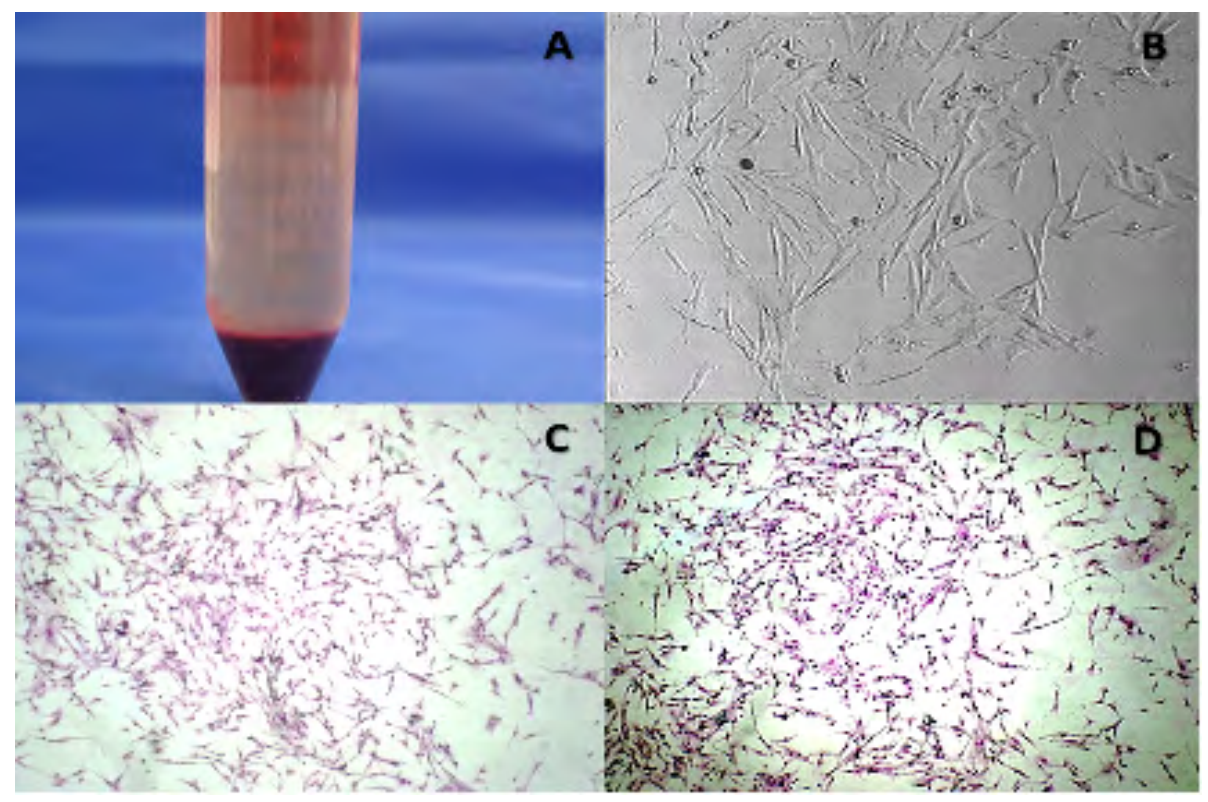

Figure 1. Isolation, culture and assay of colony-forming units of mesenchymal stem cells from bone marrow of legs. A: photography ring of mononuclear cells after separation with Ficoll®. B: Plastic adherent mesenchymal cells, 10X magnification. C: test of colony forming units, magnification 10x. D: assay of colony forming unit, magnification 10x.

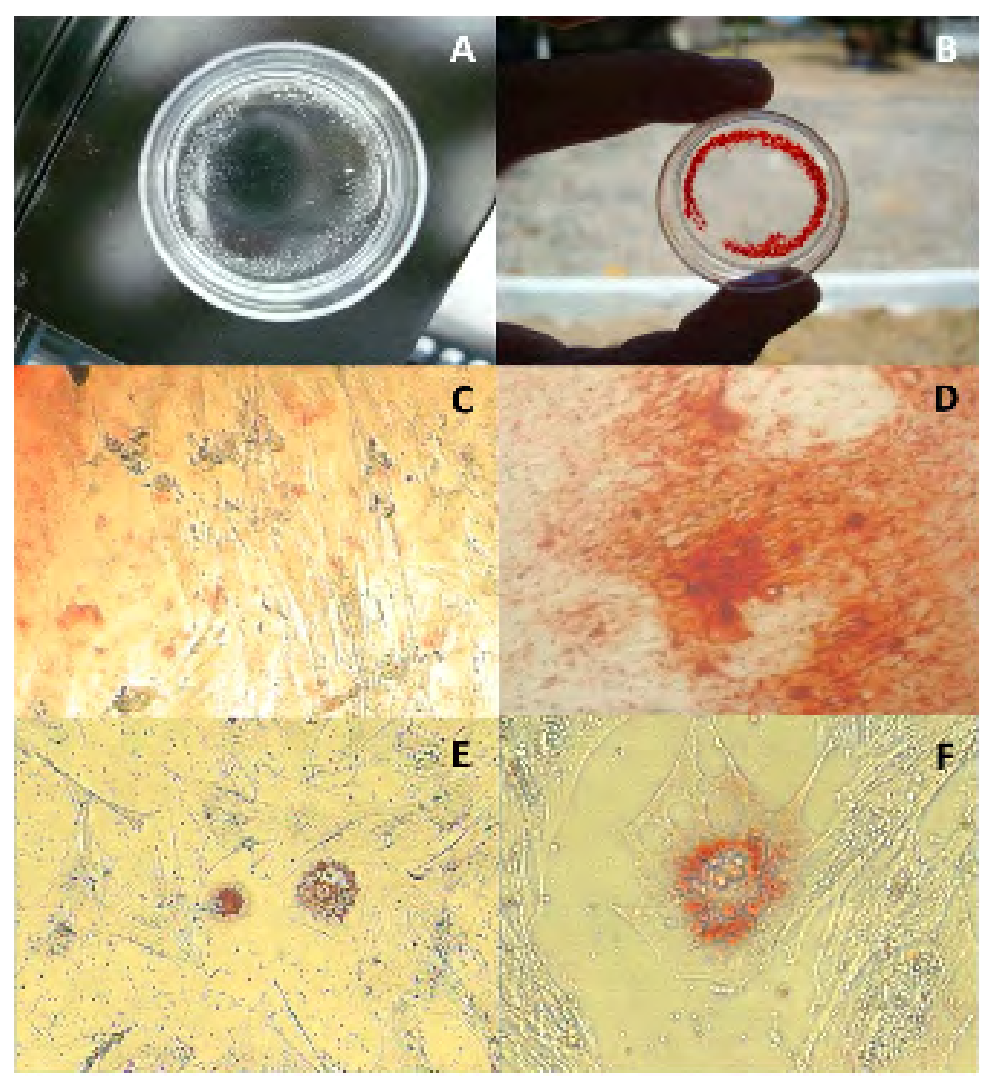

Figure 2. Osteogenic and adipogenic differentiation of stem cells from bone marrow of leg. A: Petri dish with calcium deposits. B: Bone Matrix stained with Alizarin Red. C: Petri plate stained with Alizarin Red, 10X magnification. D: Bone matrix stained with Alizarin Red, increase 5x. E: Beads lipid stained with oil red, 10X magnification. F Granule of Lipid stained with Oil Red, up 20x. 


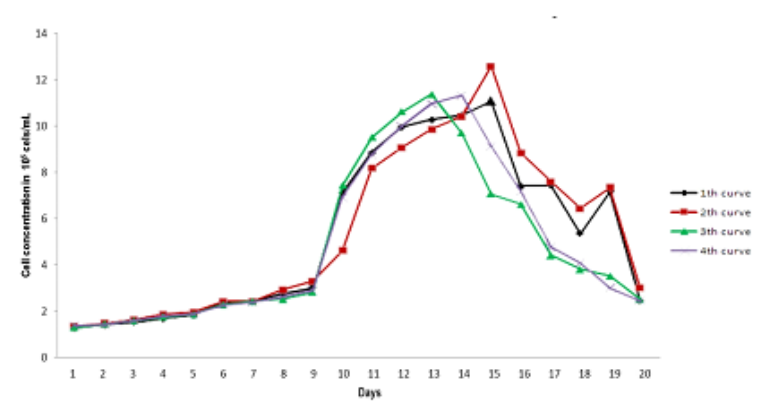

Graph 1. Pre-freezing growth kinetics assay saturation in mesenchymal stem cells culture from the bone marrow of collared peccaries. Tested in quadruplicate. The curves ascended evenly until the ninth day of observation, when the logarithmic phase became clear and the cell concentration of the samples increased progressively until it reached the curve saturation plateau between the 13th and 16th day. The plateau phase did not show typical feature, with ascending and descending points. After the interval, the culture became exhausted and the cell concentration declined progressively.

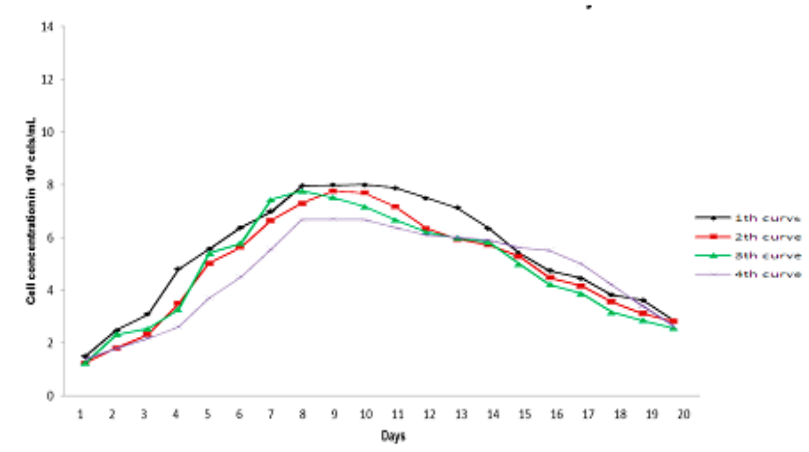

Graph 2. Post-freezing growth kinetics essay in mesenchymal stem cells culture from the bone marrow of collared peccaries.

Table 1. Mean values of concentration and cell viability of bone marrow mononuclear fraction of peccaries, colony-forming unit-fibroblast and viability of mesenchymal stem cells isolated and expanded for 15 passages.

\begin{tabular}{ccccc}
\hline $\begin{array}{c}\text { BONE } \\
\text { MARROW } \\
\text { SAMPLES }\end{array}$ & $\begin{array}{c}\text { CELL CONCENTRATION } \\
\text { MONONUCLEAR } \\
\text { FRACTION (CELLS/mL) }\end{array}$ & $\begin{array}{c}\text { INITIAL } \\
\text { SAMPLE } \\
\text { VIABILITY }\end{array}$ & $\begin{array}{c}\text { COLONY- } \\
\text { FORMING UNIT- } \\
\text { FIBROBLAST }\end{array}$ & $\begin{array}{c}\text { VIABILITY AFTER } \\
\text { EXPANDING BY 15 } \\
\text { PASSAGINGS }\end{array}$ \\
\hline 1 & $5.43 \times 10^{6}$ & $96 \%$ & 65.41 & $96 \%$ \\
2 & $6.37 \times 10^{6}$ & $95 \%$ & 56.15 & $95 \%$ \\
3 & $6.27 \times 10^{6}$ & $92 \%$ & 63.33 & $94 \%$ \\
4 & $5.37 \times 10^{6}$ & $95 \%$ & 58.44 & $95 \%$ \\
\hline MEANS & $5.86 \pm 0.5 \times 10^{6}$ & $94.5 \%$ & $60.83 \pm 4.27$ & $95 \%$ \\
\hline
\end{tabular}

\section{DISCUSSION}

The discreet presentation of the whitish halo of mononuclear cells (Figure 1A) observed in the present study was probably due to the small volume of bone marrow blood collected, and halos equally discreet have been described from small blood volumes from mice [15-17] and from the wild agouti species (Dasyprocta prymnolopha) [18], and thick and evident halos in large volumes of blood obtained from humans [19,20], pigs [21] and horses [22] and cattle [23].

The reduced thickness of the mononuclear halo was reflected in a lower mean cell concentration obtained compared to the other species. A study on a wild species reported mean $10^{8}$ cells $/ \mathrm{mL}$ mononuclear cell concentration [18]. Studies with domestic pigs [24] and cats [25] have reported concentrations of 1.8 x $10^{8}$ and $2.3 \times 10^{8}$ cells $/ \mathrm{mL}$, respectively. However, in the present experiment the mean concentration of $5.86 \pm 0.5 \times 10^{6}$ mononuclear cells $/ \mathrm{mL}$ was satisfactory to isolate and expand the MSC in the relatively short period of 25 days.

The data obtained in the CFU-F assay (Table 1) were similar to those observed by [24] and [26] who obtained a mean number of CFU-F in pig bone marrow blood of $68.58 \pm 20.61$ and $69.25 \pm 19.32$ colonies, respectively. In spite of this similarity, [27] reported that the number of CFU-F in a sample can differ among species and is influenced by the culture media conditions [28]. Further stated that the number of CFU-F obtained is only an indication of the potential of the sample collected in counting mesenchymal stem cell and it should not be used to assess directly in the presence of these cells in the sample, due to the great morphological heterogeneity of the CFU-F within the same species. Thus, 
the results obtained indicated that there was similarity between the bone marrow potential for MSC isolation in the domestic pig and collared peccary.

The in vitro performance of the culture during the cell isolation phase was very similar to that observed in MSC culture of mice [15], rats [27], pigs [25] and humans [29]. According to these authors although some cells from the reticulate-phagocyte system can adhere for a short time to the plastic substrate of the collective well, only the MSC adhere for a long time. The capacity for prolonged time adhesion is an intrinsic characteristic of the mesenchymal stem cell [28] and in this way the successive washes remove only the contaminating cells.

The fibroblast-like-cell morphology presented by the cells during the cell isolation and expansion phases (Figure 1B) has already been reported in different animal species and in man [17,20,21,28] for MSC culture. Although these studies diverged regarding cell morphometry, they all described the morphology of these cells as varying between the fibroblastoid and fusiform, depending on the anatomic site used for collection. However retrospective studies [28,30,31] have discussed that both the morphology and identification of the cell-surface markers, analyzed alone or together, are not specific to properly define the MSC, regardless of their isolation niche. Innumerous discrepancies have been observed, such as the positive identification of the STRO-1 marker in stromal MSC [31,32] and absence of this marker in the adipogenic MSC [33,34]. The conflict persists among studies with MSC isolated from the same anatomic niche and has been identified as CD 10 positive by [32] and negative by [35] and [36]. The most suitable identification method for MSC is prolonged proliferation in culture with morphology maintenance and differentiation capacity in at least two cell lines $[28,31,30]$. Obviously, the association among different forms of cell identification widens the possibility of reliable characterization of MSC populations and should always be considered.

As the collared peccary is a wild species and because this is the first study of this kind, there are no commercial antibodies available for cell characterization in the species, nor are studies available that assess the cross-reactivity with antibodies for the domestic pig. Thus it was chosen to assess the prolonged proliferation in culture and the differentiation capacity to identify the cells in the present study.
The cell differentiation assay clearly showed differentiation of the MSC in the adipogenic and osteogenic lines (Figure $2 \mathrm{~A}-\mathrm{F}$ ), by identifying calcium deposits and fat vacuoles inside cells. Both the methodology and the results obtained had already been reported in humans and domestic animals [25,31,37,38] but to date there have been no comparative studies with wild animals. The similarly observed in the differentiation of the collared peccary MSC, with differentiation studies in other species, suggested that, in spite of the heterogeneity of the MSC populations, these cells share similar differentiation potential. Thus the collared peccary can be considered as an alternative and viable model for stromal MSC acquisition and studies with cell therapy.

The performance of the MSC in growth curve (Graph 1) observed in the present study has already been described for other cell types [37,38]. According to these authors increase in cell concentration exhausts nutrients in the culture media, leading to cell death and reduced concentration in the samples studied. However, the MSC culture was highly viable, that is in agreement with the cell viability observed during the expansion assay of the cultures. In this case, nutrient exhaustion in the culture media is the probable cause of the decline in viability, as proposed by other authors $[37,38]$.

Reduced cell viability after thawing, observed in the present study (Graph 2), had already been described in different studies with human and animal MSC [17,39-41]. In the present study, as thawing was quick in a water bath, it is possible that the heat-shock resulting from the abrupt change in cell temperature increased the permeability of the plasma membrane and contributed to the positive marking in the trypsin blue test, thus reducing the viability of the samples. This possibility had already been suggested by other author [28], but has not been confirmed scientifically.

In studies with human MSC cryopreservation $[39,40,42]$ reported apoptosis rates of $17.5 \%, 16.3 \%$ and $18.3 \%$, respectively. According to these authors, cell freezing can induce apoptosis by an increase in the expression of the genes of the Bcl-2 family, such as Bax and $\mathrm{Bcl}-2$. Thus, depending on the freezing and thawing conditions, these cells can be viable after thawing, but one part of the cells ends up suffering programmed cell death. It is possible that the same mechanism occurs in domestic and wild animal MSC, but further studies are needed to confirm this hypothesis. In the 
present study, early culture exhaustion seemed not to be related to nutrient exhaustion in the culture media because there was no cell concentration that surpassed the capacity of the medium, thus it is believed that a decrease in the cell viability may have been related to the increase in apoptosis after thawing.

Some studies also suggested that the cryopreservation method interfered negatively but discreetly in MSC adhesion in horses and humans $[17,39,40]$. These authors assessed the immune phenotype of equine stromal MSC and human adipogenic stromal MSC, respectively, before and after thawing and observed increase in the $\alpha 4$ (CD49d) expression. It is believed that these mechanisms may be involved alone or together in decreasing the cell viability after thawing in the present study, but further studies are needed to assess these hypotheses.

Regarding the safety of the collared peccary stromal stem cell collection, the protocol for anesthesia and bone marrow puncture used in the present study was efficacious, shown by the hemodynamic stability presented by the animals during collection. This observation is ratified by previous studies in collared peccaries and domestic pigs, that used ketamine, diazepam, propofol and midazolam, and good tranquilization was obtained and little variation in the arterial pressure levels [43-45].

\section{CONCLUSIONS}

In conclusion, the results demonstrated the presence of a well-defined MSC population in the collared peccary bone marrow, with high in vitro replication rate and differentiation potential confirmed for the adipogenic and osteogenic lines. In spite of the small volume of bone marrow blood collected, the technique of cell separation by concentration gradient by Ficoll was efficacious, maintaining cell viability maintenance above $90 \%$ and MSC isolation and expansion in the relatively short period of 35 days. The cryopreservation technique adopted presented satisfactory results, but indicated a significant cell stress after thawing that justifies investigation of the apoptosis rates induced post thawing in the species. Furthermore, the bone marrow collection did not harm the animals and the facility of stromal MSC isolation and culture qualifies the collared peccary as a viable alternative model to obtain MSC and for studies in the area of cell therapy.

\section{MANUFACTURERS}

${ }^{1}$ Aldrich Corporation. Saint Louis, MO, USA.

${ }^{2}$ Life Technologies Corporation. Grand Island, NY, USA.

${ }^{3}$ Agribands Brasil Ltda. Paulínia, SP, Brazil.

${ }^{4}$ Cristália Produtos Químicos Farmacêuticos Ltda. Itapira, SP, Brazil. ${ }^{5}$ Lapon Química e Natural Ltda. Limoeiro, PE, Brazil.

${ }^{6}$ Pharmaceutical Suppliers Solutions. Dublin, Ireland.

${ }^{7}$ Amgen Inc. Santo Amaro, SP, Brazil.

${ }^{8}$ Virbac Industria e Comércio Ltda. Jurubatuba, SP, Brazil

${ }^{9}$ Ouro Fino Saúde Animal. Cravinhos, SP, Brazil.

${ }^{10}$ Cultilab Materiais para Cultura de Células Ltda. Campinas, SP, Brazil

${ }^{11}$ Techno Plastic Produts. Trasadingen, Switzerland.

${ }^{12}$ Microscopy Software and Imaging. Jena, Germany.

${ }^{13}$ Sony Corporation of America. New York, NY, USA.

${ }^{14}$ Diagnostic Instruments Inc. Sterling Heights, MI, USA.

${ }^{15}$ Microsoft Company. Redmond, WA, USA.

${ }^{16}$ Business Intelligence. Las Vegas, NE, USA.

Acknowledgements. Coordination for the Improvement of Higher Level -or Education- Personnel (CAPES); National Council for Scientific and Technological Development (CNPq); Brazilian Institute of Environment and Renewable Natural Resources (IBAMA).

Ethical approval. This experiment was approved and performed under the guidelines of Ethics Committee in Animal Experiments (CEEA) of the Federal University of Piauí (UFPI), according to statement $\mathrm{n}^{\circ} 060 / 11$, in accordance to the regulations of the Brazilian Collegiate of Animal Experimentation (COBEA) and the Brazilian Institute of Environment and Renewable Natural Resources (IBAMA - SISBIO/ICMBio no. 19254-1).

Declaration of interest. The authors report no conflicts of interest. The authors alone are responsible for the content and writing of the paper.

\section{REFERENCES}

1 Augello A., Kurth T.B. \& Bari C. 2010. Mesenchymal stem cells: a perspective from in vitro to in vivo migration and niches. European Cells \& Materials. 20(1): 121-133.

2 O., Babaei H., Derakhshanfar A., Nematollahi-Mahani S.N., Poursahebi R. \& Moshrefi M. 2011. Effects of transplanted mesenchymal stem cells isolated from Wharton's jelly of caprine umbilical cord on cutaneous wound healing; histopathological evaluation. Veterinary Research Communications. 35(4): 211-222. 
3Bland M. 2000. An Introduction to Medical Statistics. 3rd edn. NewYork: Oxford University Press, 405p.

4Bosnakovski D., Mizuno M., Kim G., Takagi S., Okumura M. \& Fujinaga T. 2005. Isolation and multilineage differentiation of bovine bone marrow mesenchymal stem cells. Cell and Tissue Research. 319(2): 243-253.

5Cabrera A., Yepes J. \& Wiedner C.C. 1940. Mamiferos Sud-Americanos (Vida, Costumbres y Descripcion). Buenos Aires: Compañia Argentina de Editores, 370p.

6Chang Y., Hsieh P.H. \& Chao C.C.K. 2009. The efficiency of percoll and ficoll density gradient media in the isolation of marrow derived human mesenchymal stem cells with osteogenic potential. Chang Gung Medical Journal.32(3): 264275.

7Chen K., Baxter T., Muir W.M., Groenen M.A. \& Schook L.B. 2007. Genetic resources, genome mapping and evolutionary genomics of the pig (Sus scrofa). International Journal of Biological Sciences. 3(3): 153-165.

8Corn D.J., Kim Y., Krebs M.D., Mounts T., Molter J., Gerson S., Alsberg E., Dennis J.E. \& Lee Z. 2013. Imaging early stage osteogenic differentiation of mesenchymal stem cells. Journal of Orthopaedic Research. 31(6): 871-879.

9Covas D.T., Panepucci R.A., Fontes A.M., Silva Jr. W.A., Orellana M.D., Freitas M.C., Neder L., Santos A.R., Peres L.C., Jamur M.C. \& Zago M.A. 2008. Multipotent mesenchymal stromal cells obtained from diverse human tissues share functional properties and gene-expression profile with CD146+ perivascular cells and fibroblasts. Experimental Hematology. 36(5): 642-654.

10 Desbiez A.L.J., Santos S.A., Keuroghlian A. \& Bodmer R.E. 2009. Niche partitioning among white-lipped peccaries (Tayassu pecari), collared peccaries (Pecari tajacu), and feral pigs (Sus scrofa). Journal of Mammalogy. 90(1): 119128.

11 Deus G.C., Normanton M., Hamerschlak N., Kondo A.T., Ribeiro A.A.F., Goldberg A.C. \& Marti L.C. 2012. Isolation and characterization of mesenchymal stem cells obtained from reusable and disposable bone marrow collection filters. Einstein. 10(3): 296-301.

12 Dorandeu F., Mikler J.R., Thiermann H., Tenn C., Davidson C., Sawyer T.W., Lallement G. \& Worek F. 2007. Swine models in the design of more effective medical countermeasures against organophosphorus poisoning. Toxicology. 233(1-3): 128-144.

13 Ginis I., Grinblat B. \& Shirvan M.H. 2012. Evaluation of bone marrow-derived mesenchymal stem cells after cryopreservation and hypothermic storage in clinically safe medium. Tissue Engineering Part C: Methods. 18(6): 453463.

14 Goh B.C., Thirumala S., Kilroy G., Devireddy R.V. \& Gimble J.M. 2007. Cryopreservation characteristics of adipose-derived stem cells: maintenance of differentiation potential and viability. Journal of Tissue Engineering and Regenerative Medicine. 1(4): 322-324.

15 Gronthos S, Zannettino A.C., Hay S.J., Shi S., Graves S.E., Kortesidis A. \& Simmons P.J. 2003. Molecular and cellular characterisation of highly purified stromal stem cells derived from human bone marrow. Journal of Cell Science. 116(9): 1827-1835.

16 Irioda A.C., Zocche L., Souza C.M.C.O., Ferreira R.J., Aliprandini E., Cunha R.C., Francisco J.C., GuaritaSouza L.C., Malvezzi M., Beltrame M.P., Mesquita L.A.F, Kuczera D., Chachques J.C. \& Carvalho K.A.T. 2011. Pap test as the first step in screening genetic stability in cell-based therapy. Journal of Stem Cell Research \& Therapy. 1(3): 1-6.

17 Iwata T., Yamato M., Zhang Z., Mukobata S., Washio K., Ando T., Feijen J., Okano T. \& Ishikawa I. 2010. Validation of human periodontal ligament-derived cells as a reliable source for cytotherapeutic use. Journal of Clinical Periodontology. 37(12): 1088-1099.

18 Khatri M., O’Brien T.D. \& Sharma J.M. 2009. Isolation and differentiation of chicken mesenchymal stem cells from bone marrow. Stem Cells and Development. 18(10): 1485-1492.

19 Koerner J., Nesic D., Romero J.D., Brehm W., Varlet P.M. \& Grogan S.P. 2006. Equine peripheral blood-derived progenitors in comparison to bone marrow-derived mesenchymal stem cells. Stem Cells. 24(6): 1613-1619.

20 Linkenhoker J.R., Burkholder T.H., Linton C.G., Walden A., Abusakran-Monday K.A., Rosero A.P. \& Foltz C.J. 2010. Effective and safe anesthesia for yorkshire and yucatan swine with and without cardiovascular injury and intervention. Journal of the American Association for Laboratory Animal. 49(3): 344-351.

21 Liu Y., Liu L., Ma X., Yin Y., Tang B. \& Li Z. 2013. Characteristics and neural-like differentiation of mesenchymal stem cells derived from fetal porcine bone marrow. Bioscience Reports. 33(2): 351-360. 
22 Mafi P., Hindocha S., Mafi R., Griffin M. \& Khan W.S. 2011. Adult mesenchymal stem cells and cell surface characterization. The Open Orthopaedics Journal. 5(Suppl 2): 253-260.

23 Mandel, N.S., Henderson JR J.D., Hung L.Y., Wille D.F. \& Wiessner J.H. 2004. A porcine model of calcium oxalate kidney stone disease. Journal of Urology. 171(3): 1301-1303.

24 Meirelles L.S., Chagastelles P.C. \& Nardi N.B. 2006. Mesenchymal stem cells reside in virtually all post-natal organs and tissues. Journal Cell Science. 119(11): 2204-2213.

25 Meirelles L.S. \& Nardi N.B. 2003. Murine marrow-derived mesenchymal stem cell: isolation, in vitro expansion, and characterization. British Journal of Haematology. 123(4): 702-711.

26 Muscari C., Gamberini C., Basile I., Bonafé F., Valgimigli S., Capitani O., Guarnieri C. \& Caldarera C.M. 2010. Comparison between culture conditions improving growth and differentiation of blood and bone marrow cells committed to the endothelial cell lineage. Biological Procedures Online. 12(1): 89-106.

27 Nakagawa T., Nabeshima Y. \& Yoshida S. 2007. Functional identification of the actual and potential stem cell compartments in mouse spermatogenesis. Developmental Cell. 12(2): 195-206.

28 Nardi N.B. \& Meirelles L.S. 2006. Mesenchymal stem cells. Isolation, in vitro expansion and characterization. Handbook of Experimental Pharmacology. 174(1): 249-282.

29 Orciani M., Mariggio M.A., Morabito C., Di B.G. \& Di P.R. 2010. Functional characterization of calcium-signaling pathways of human skin-derived mesenchymal stem cells. Skin Pharmacology and Physiology. 23(3): 124-132.

30 Penny J., Harris P., Shakesheff K.M. \& Mobasheri A. 2012. The biology of equine mesenchymal stem cells: phenotypic characterization, cell surface markers and multilineage differentiation. Frontiers in Bioscience. 17(1): 892-908.

31 Peterbauer-Scherb A., Griensven M., Meinl A., Gabriel C., Redl H. \& Wolbank S. 2010. Isolation of pig bone marrow mesenchymal stem cells suitable for one-step procedures in chondrogenic regeneration. Journal of Tissue Engineering and Regenerative Medicine. 4(6): 485-490.

32 Purriños M.R., Vazquez F.F., Prado A.P., Altonaga J.R., Ramon C.C., Silverio J.M.A., Orden A. \& Orden J.MG. 2011. Ventricular arrhythmias and mortality associated with isoflurane and sevoflurane in a porcine model of myocardial infarction. Journal of the American Association for Laboratory Animal Science. 50(1): 73-78.

33 Ranera B., Lyahyai J., Romero A., Vázquez F.J., Remacha A.R., Bernal M.L., Zaragoza P., Rodellar C. \& Martín-Burriel I. 2011. Immunophenotype and gene expression profiles of cell surface markers of mesenchymal stem cells derived from equine bone marrow and adipose tissue. Veterinary Immunology and Immunopathology. 144(1-2): 147-154.

34 Redzić A., Smajilagić A., Aljicević M. \& Berberović L. 2010. In vivo osteoinductive effect and in vitro isolation and cultivation bone marrow mesenchymal stem cells. Collegium Antropologicum. 34(4): 1405-1409.

35 Ribeiro G., Massoco C.O. \& Lacerda Neto J.C. 2012. Viabilidade celular da fração mononuclear da medula óssea e fração vascular estromal do tecido adiposo de equinos após o processo de congelamento e descongelamento. Pesquisa Veterinária Brasil. 32(Suppl 1): 118-124.

36 Rocha A.R., Alves F.R., Argôlo Neto N.M., Santos L.F., Almeida, H.M., Carvalho Y.K.P., Bezerra D.O., Ferraz M.S., Pessoa G.T. \& Carvalho M.A.M. 2012. Hematopoietic progenitor constituents and adherent cell progenitor morphology isolated from black-rumped agouti (Dasyprocta prymnolopha, Wagler 1831) bone marrow. Microscopy Research Technique. 75(10): 1376-1382.

37 Shi C., Zhu Y., Su Y. \& Cheng T. 2006. Stem cells and their applications in skin cell therapy. Trends in Biotechnology. 24(1): 48-52.

38 Short B., Brouard N., Occhiodoro-Scott T., Ramakrishnan A. \& Simmons P.J. 2003. Mesenchymal stem cells. Archives of Medical Research. 34(6): 565-571.

39 Souza A.W.S., Neves R.M.S., Oliveira K.R. \& Sato E.I. 2006. Tratamento de arterite de Takayasu. Revista Brasileira de Reumatologia. 46(Suppl 1): 2-7.

40 Tsai M.S., Lee J.L., Chang Y.J. \& Hwang S.M. 2004. Isolation of human multipotent mesenchymal stem cells from second-trimester amniotic fluid using a novel two-stage culture protocol. Human Reproduction. 19(6): 1450-1456.

41 Uccelli A. \& Prockop D.J. 2010. Why should mesenchymal stem cells (MSCs) cure autoimmune diseases? Current Opinion Immunology. 22(6): 768-774.

42 Webb T.L., Quimby J.M. \& Dow S.W. 2012. In vitro comparison of feline bone marrow-derived and adipose tissuederived mesenchymal stem cells. Journal of Feline Medicine and Surgery. 14(2): 165-168. 
43 Xu J., Qian J., Xie X., Lin L., Zou Y., Fu M., Huang Z., Zhang G., Su Y. \& Ge J. 2012. High density lipoprotein protects mesenchymal stem cells from oxidative stress-induced apoptosis via activation of the PI3K/Akt pathway and suppression of reactive oxygen species. International Journal of Molecular Sciences. 13(12): 17104-17120.

44 Xu S., Becker A., Camp B.V., Vanderkerken K. \& Riet I.V. 2010. An improved harvest and in vitro expansion protocol for murine bone marrow-derived mesenchymal stem cells. Journal of Biomedicine and Biotechnology. October: $1-10$.

45 Zhou Y., Yan H., Guo M., Zhu J., Xiau Q. \& Zhang L. 2013. Reactive oxygen species in vascular formation and development. Oxidative Medicine and Cellular Longevity. January: 1-14. 